\title{
European Mask: Faces of Japanese Imperialism
}

\author{
Mellissa Severson-Hampton
}

The image and idea of what cultural property entails often remains elusive and begs the question, "What is cultural property?"

Another way of thinking about cultural property is as part of a national cultural heritage. This gives nations a special interest, implies the attribution of national character to objects, independently of their location or ownership, and legitimizes national export controls and demands for 'repatriation' of cultural property. ${ }^{1}$

When defined in this context, cultural property assumes the form of objects that appeal to the sense of identity of a nation and the nation's citizens, regardless of where those objects may have ended up. With this definition in mind, a firmer stance can be taken on the importance of cultural property to the continuation and reproduction of a culture. When looking at the war crimes committed by the Japanese during World War Two, the aspect of cultural looting is often overlooked, particularly when juxtaposed to the other atrocities committed by the Japanese during this time. The ties between Japan's cultural looting and other war crimes are clear: these acts of cultural looting worked in tandem with the Japanese goal of total domination and control of Asia. Though the committing of war crimes, the Japanese sought to control over China and other Asian countries. To explore the use of war crimes and cultural looting as an aspect of expansion, imperial policies must be referred to. "In its most general sense, imperialism refers to the formation of an empire...," however, "Edward Said uses imperialism in this general sense to mean the practice, theory and the attitudes of a dominating metropolitan centre ruling a distant territory.", To further clarify, "from the 1880's imperialism became a dominant and more transparently aggressive policy amongst European states for a variety of political, cultural and economic reasons." 3 In order to validate the aggression of these imperial states, "the idea of expansion could be seen, and was presented, in terms of the improvement of the lot of the "barbaric nations." "4 The attitudes of superiority and 'benevolent' teacher dominate the ideals invoked by imperialism. The ways in which Imperialist countries in the west established control and dominance over conquered territories played a vital role in influencing the way Japan expanded. The actions conducted by Japan in reference to cultural looting and the systematic and coordinated efforts to collect Chinese books and manuscripts can be compared to similar actions of Imperialism conducted by Western Imperialist countries. In a comparison to Norway, the reeducation and Norwegianization of the Sami in Norway can be linked to the goal of Japanese reeducation and domination of Asia. The ties between Western Imperialist practices and Japan's emerging role as an Imperi-

\footnotetext{
${ }^{1}$ John Henry Merryman, “Two Ways of Thinking About Cultural Property," The American Journal of International Law, Vol. 80, No. 4 (Oct., 1986), p. 832. (JSTOR).

${ }_{2} 2$ Bill Ashcroft, Gareth Williams, and Helen Tiffin, Post-Colonial Studies: The Key Concepts, (New York:Routledge, 2000) p. 122.

${ }^{3}$ Ibid.

${ }^{4}$ Ibid., p. 123.
} 
alist power can be used to explore the outlook and intentions of Japan concerning cultural property in the past and present.

When exploring the issue of Japanese cultural looting, the actions must first be understood in the context of what the intent behind the acts were, and what type of actions the looting personified. Japan's actions may be understood in the context of a typical imperialist mindset. In the words of the British Union of Democratic Control, "China was plainly the first, and remains the main object of Japanese Imperialism." Seen as an object of desire for Japanese control, China had to first be established as a weak and barbaric country. As Japan industrialized and modernized, the ideals of western expansion influenced Japan. This imperialist influence the west held over Japan can be seen in the language and actions of Japan. In an address presented by Japan to the United States in 1937, Japan sets the tone with an imperialistic message,

Surely, China, with a population of over four hundred millions of people and a territory as large as that of Europe, should be able to take care of herself. If she is not, whose fault is it? And also, why should it be the duty of distant nations to save her from the disasters her leaders have brought upon her? ${ }^{6}$

In this one statement Japan not only portrays China as a weak and therefore inferior nation and culture, but creates a rational for action to be taken upon China by Japan. As not only the strongest oriental nation, but also the strongest nation that had cultural and linguistic ties to China, Japan was obligated to 'help' China. In order to facilitate Japan's parental role with China, Japan asks the question, why would distant and 'other' nations be put upon to help the feminized weak nation of China when the culturally related nation of Japan is closer not only geographically, but also culturally, linguistically and historically? Suma asserted,

Japan is the one nation of the Orient that has taken to heart the teachings of the West and amply profited by them. The State is modernized; general education is given to the young, girls as well as boys; law and order prevail in the land the same as in any Western country; the welfare of the people is generally promoted by the Government in which the people themselves take an active part. $^{7}$

As the only nation in the Orient that had taken to heart the western teachings and profited by them, Japan maintained the right to appeal to Western ideals while at the same time maintaining independence from Western control. Japan therefore assumed the authority to bring this Western enlightenment into the Orient onto itself because Japan had undertaken a transformation with Western ideals and thought and emerged, transcending the expectations of the West. Japan therefore appealed to the paternal nature of fellow imperialists in order to condone Japan's actions.

Wherever Western nations have gone into backward countries, they have improved the condition of the people. Is not that true? Well, then, why not recognize the fact that what Japan has done for others has also been of merit.

\footnotetext{
${ }^{5}$ Union of Democratic Control, Eastern menace; the story of Japanese imperialism. London: Union of Democratic Control, 1936. p. 23.

${ }^{6}$ Yakichiro Suma, "What Japan Wants In China" (Address before the Buchnell University Christian Association, Lewisburg, Pennsylvania, December 10, 1937) in Where Japan Stands; Addresses Delivered in America on the Sino-Japanese Conflict (Tokyo: The Hokuseido Press, 1940), p. 57.

${ }^{7}$ Ibid., p. 59.
}

16 | Journal of Contemporary Eastern Asia, Volume 8, No.2 
With all her shortcomings_-which are numerous_-Japan has vastly improved the lot of the native people in every territory she has entered. ${ }^{8}$

With this comment, Suma connects the West's dominant image as paternal figure and the role of the 'white man's burden' with the actions the Japanese were undertaking in the Orient. The ends justify the means, because the 'lot of the native people' has been vastly improved by the dominion of the West. The West could therefore not argue with the intentions of Japan to bring Western ideals into the so called 'backward' nations in the orient when they, the West, used that context to justify and condone actions the West partook of around the world. With European competition and subsequent colonialism as a result of that European imperialist competition, the strengthening of China from Japan could be seen as a matter of self protection and as a buffer against expansionist threats. Japan asserted, "We wanted China to be secure so that there would be no repetition of the encroachments from Europe upon her sovereignty." "This desire to protect oneself through the strengthening of the surrounding territories was a typical strategy employed by the imperialist European countries.

With Japanese stated intentions and the rationale for expansion around Japan and Japan's attitude towards China made clear, the development of plans concerning China can be explored through the emblematic imperialist actions. As Japan modernized, the expansionist influence of the West and Western ideas can be seen in the subsequent actions Japan undertook in regards to China. The colonialist method of supplanting the local indigenous culture and reeducation with a focus on certain Western ideals appealed to Japan. In order to strengthen the East, the surrounding weak Oriental cultures would have to be broken down and replaced with Japanese sanctioned ideas and culture. Because Japan was the only Oriental nation that had the ability to withstand Western pressure and industrialize, the culture and ideals of Japan were therefore fundamentally superior according to the Japanese mindset. Japan's goal of a Pan-Asian movement could be realized through the imperialist reeducation policies Japan learned from the West. Suma explains Japan's objectives, "What does Japan want? Where does Japan stand? These questions are easily answered. There is nothing sinister or obscure about Japan's purposes in China. Japan's only object is to obtain a change of attitude by China." "Japan systematically undertook action to achieve the 'change in attitude' in China. Suma predicted,

The writers of the future, I venture to predict, will say that after a century of Western effort to induce the Chinese to change, the Manchu Dynasty was overthrown and the country was called a Republic, but that it remained in much the same state of backwardness that it had been in for centuries before. The Chinese historians will record, however, that in the year 1938 a great change had its beginning, and for that change they will give credit to a farseeing Japan. ${ }^{11}$

Japan's parental role in China was therefore to civilize and bring China into the present and out of the backward phase China had apparently allowed herself get into through isolation

\footnotetext{
${ }^{8}$ Ibid.

${ }^{9}$ Ibid., p. 53.

${ }^{10}$ Yakichiro Suma, "Where Japan Stands" (Address before the Economic Club of Detroit, Michigan, December 12, 1937) in Where Japan Stands; Addresses Delivered in America on the Sino-Japanese Conflict (Tokyo: The Hokuseido Press, 1940), p. 69.

${ }^{11}$ Yakichiro Suma, "A Long View of the East" (Address at the "Japan Night" Program, International Student's House, Philadelphia, Pa., March 3, 1939) in Where Japan Stands; Addresses Delivered in America on the SinoJapanese Conflict (Tokyo: The Hokuseido Press, 1940), p. 213.
} 
and weakness of leadership. In order to bring China out of this darkness of 'barbarity', immediate actions with long range objectives were undertaken. "The immediate goal of the slaughtering and looting was the destruction of Chinese nation and its cultural tradition. The objective was the establishment of the Greater East Asia Co-prosperity Sphere in Asia. Japan would be its leader and chief beneficiary." 12 The way in which to establish total control and influence over China was then not in the militaristic sense. Suma again maintains,

We Japanese are not under the illusion that we can conquer China. A nation of $400,000,000$ people cannot be "conquered" in the military sense of the word. Our purpose is to swab out the sources of infection within China which have poisoned her relations with our country. ${ }^{13}$

The role of reeducation and cultural control superseded the role of the military in the overall long-term objective of control over Asia. The militaristic actions undertaken by the Japanese were the first phase of the objective to take over Asia. The introduction of Japanese culture and ideals would provide a stronger, more stable, hold on Asia than any permanent military force Japan could provide. Japan's long range goal of creating a Greater East Asia Coprosperity Sphere in Asia could only be successful through reeducation. To accomplish this reeducation, Japan focused on the 'source of infection' in China. According to Suma,

Very soon it became clear that the real purpose of the new Nanking Government was to unify the country by means of an inspired campaign against Japan...The official textbooks used in Chinese schools were filled with lessons of hatred against Japan, which was described as the chief cause of China's troubles. $^{14}$

The targeting of cultural materials and books by the Japanese could then be justified in that the Chinese were using textbooks and other materials to infect the minds of the Chinese against the interests of Japan. The Japanese framed Chinese educational institutions as places of unrest and disobedience and focused on destroying the schools. In an address to the United States, Madame Chiang reported Japanese actions, "The Japanese military have with calculated ferocity bombed all Chinese educational institutions they could locate, claiming that those institutions were hotbeds of resistance against Japanese efforts to dominate China" ${ }^{15}$ As the Japanese believed the school texts were poisoning minds against Japan, the schools and places of knowledge such as libraries received first priority in order to control the spread of knowledge and dissent among Chinese. In a letter delivered from the "Headquarters of the Generalissimo, Wuchang, China" dated February 25, 1938, Madame Chiang Kai-Shek replied to a US doctor with the following comments,

So intent are the Japanese upon the calculated destruction of China that not only are the people being wiped out but every factory and every school that

\footnotetext{
${ }^{12}$ Zhao Jianmin, "The Looting of Books in Nanjing," in Peter Li, eds., The Search for Justice: Japanese War Crimes (New Brunswick: Transaction Publishers, 2003), p. 283.

${ }^{13}$ Yakichiro Suma, "New Order in East Asia" (Published in the "Harvard Guardian," April, 1939) in Where Japan Stands; Addresses Delivered in America on the Sino-Japanese Conflict (Tokyo: The Hokuseido Press, 1940), p. 233.

${ }^{14}$ Suma, "Where Japan Stands," p.65.

${ }^{15}$ May-ling Soong Chiang, "Young China's contributions to world thought being disrupted by Japanese destroyers of culture" (Madame Chiang Cables to U.S. Students) in War Messages and Other Selections (Hankow: The China Information Committee, 1938), p. 157.
}

18 | Journal of Contemporary Eastern Asia, Volume 8, No.2 
the Japanese can reach is being demolished. The Japanese are transporting to Japan everything they can collect in China of value. ${ }^{16}$

The cultural property of China was valuable, so while the schools and places of culture were destroyed, the contents were worthy of looting and bringing back to Japan. The relationship between China's self identity and the history and culture contained within the books and materials looted was self evident. Because the looting focused on the scrolls, texts, and historical documents associated with the formation of Chinese identity through knowledge of the past, the accumulation of these cultural properties became an important weapon in Japan's arsenal.

According to the statistics of 1936 compiled by the Chinese Libraries Association, on the eve of the Japanese invasion there were 4,747 libraries in all throughout China, including independent libraries, school libraries, institutional libraries and county and municipal libraries. But by 1943, however, following the Japanese invasion and occupation, the number of libraries declined to $940 .{ }^{17}$

Although few libraries were left intact, the books were not destroyed along with the libraries. The Japanese desired the total control of the people and resources of China, and the looting of books was emblematic of the control of Japan over the cultural heritage and history of the nation of China. "According to the documents from Japan and China, during the Nanjing massacre the Imperial Japanese Army was also engaged in the systematic looting and plundering of a total of 897,178 volumes of books from a large assortment of libraries in Nanjing." 18 The looting of books and cultural materials stripped China of a sense of self and can arguably raised to the status of war crimes because of the threat of the loss of national identity, history and culture inherent in the loss of the books and cultural heritage of a nation.

As a Japanese scholar has pointed out, '[even though] the Japanese military's looting of books [may not appear to be] in the same order of importance as the seizing of sovereign territory and property, taking over of markets or slaughtering of people, actually the looting of books is an extension of the seizing of territory and property and an important part of Japan's policy of annihilating a nation and subjugating its people, 19

The subjugation of the Chinese people through the imposition of Japanese culture and Japan's stance concerning Chinese culture as inferior enabled further atrocities to be visited upon the Chinese. Japan's view of China as culturally inferior, and the need for reeducation, worked to corroborate and reinforce any action needed to bring China to a position in which Japan could begin to make changes to 'better' China. "It is not difficult to see that Japan regarded the looting of books to be an important part of its overall military strategy." 20 The imperialist action of imposing the dominant culture onto the conquered colonial territories served Japan well in the goal for the creation of a Greater East Asia Co-prosperity Sphere.

\footnotetext{
${ }^{16}$ May-ling Soong Chiang, "Response letter to U.S. doctor" (Headquarters of the Generalissimo, Wuchang, China, February 25, 1938) in War Messages and Other Selections (Hankow: The China Information Committee, 1938), p. 189.

17 Jianmin, "The Looting of Books in Nanjing," p. 281.

${ }^{18}$ Matsumoto, Tsuyoshi, Ryakudatsu shita bunka-senso to tosho [Cultural Looting-War and Books] (Tokyo: Iwanami shoten, 1993), pp. 75-80. quoted in Zhao Jianmin, "The Looting of Books in Nanjing," in Peter Li, eds., The Search for Justice: Japanese War Crimes (New Brunswick: Transaction Publishers, 2003), p. 281.

${ }^{19}$ Ibid., p. 284.

${ }^{20}$ Jianmin, "The Looting of Books in Nanjing," p. 283.
} 
"In fact, the systematic looting of books and cultural relics were an important part of Japan's expansionist policy of cultural domination of the enemy nations." 21 The action of cultural looting played such a large role in the role of conquest in China that, "After launching its full-scale invasion of China in July 1937, the Japanese Imperial Army established in its Special Task Force Section, the Central China Committee for Taking-over of Books and Documents in the Occupied Areas." 22 The military organization and attention to this aspect of the domination of China lends credence to the importance the Japanese placed on the goal of reeducation and cultural dominance.

This organization [the Central China Committee for Taking-over of Books and Documents in the Occupied Areas] was later renamed the Committee for Preparation of Materials for the Reconstruction of Central China under the Central China Liaison Institute of Asian Prosperity. ${ }^{23}$

The intentions of Japan can be seen through the renaming of the committee in charge of the books and cultural objects. The reconstruction of China would begin with the emplacement of the values and ideals of Japan, with Japan itself as the figurehead of a new solidified Asian sphere. The long range goal of a unified Orient against Western powers could only be achieved through a solidarity in culture and values that would be instilled by Japan as the dominant culture. "As some scholars have pointed out, the purpose of book looting was to destroy Chinese culture in order to fulfill the Japanese long-term objective of conquering the Asian continent." 24

Japanese intentions of domination in China and the perceived threat to Japan from outsiders can be compared with other Western imperialist acts. In the case of Norway, the Norwegianization or Fornorsking policy attempted to not only systematically eliminate the Sámi culture and language, but also to assimilate the Sámi population into the dominant culture. "The enactment of the Norwegian-oriented legislation was aimed at strengthening Norway's hold over its northern areas, which were strategically important in its relations with Russia." 25 The Norwegianization policy implies a typical imperialist reaction to European competition: the threat of encroachment of another dominant culture induced nations to strengthen internal homogeneity of culture in order to present a unified front. In order to further justify the destruction of a culture and language, the dominant culture portrayed the submissive and colonized culture as inferior.

The Norwegianization policy was partially based on social Darwinist views. Societal relationships were interpreted as a struggle between different sectors of the community. The superiority of European individuals and society was emphasized. This justified developing the 'lower' cultures, since they were assumed to be dying. ${ }^{26}$

The accepted 'truth' of Norwegian cultural and linguistic superiority over the Sámi allowed the formation and processing of legislation directed at the complete eradication of the Sámi

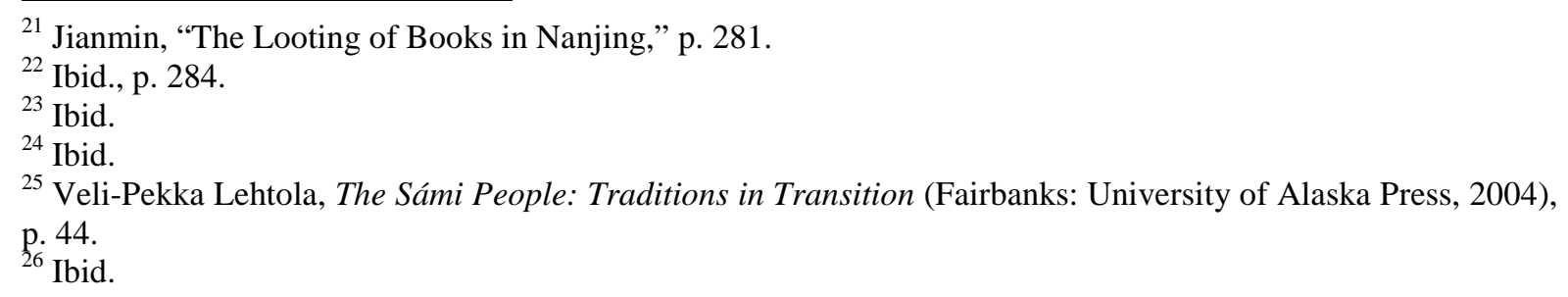

20 | Journal of Contemporary Eastern Asia, Volume 8, No.2 
way of life. In a series of legislation, the Norwegian government systematically tied legal rights and citizenship privileges to language competence.

1851- Sámi language schools were ordered to function in Norwegian. ${ }^{27}$

1864- The first decree on property ownership was based on language competence. Norwegian speakers had priority rights to buy land from the State. The definition of a Norwegian speaker was a person who could speak and read Norwegian. In the same year, the outbreak of the Danish-Prussian war over Schleswig-Holstein caused Denmark to fear that Russia would seize the northern regions. The language ordinance promoted Norwegian colonization in the north. ${ }^{28}$

1880- It was decreed that Sámi and Finnish could only be used in school as a support language. The language of institutions was Norwegian and Norwegianization was prompted in boarding houses connected to schools. ${ }^{29}$

1895- Free access to land was proclaimed, but again, only for Norwegians. Norwegian citizenship could be gained only if the authorities certified a person's mastery of the Norwegian language. ${ }^{30}$

1898- A law was passed forbidding the use of Sámi language in schools in Sápmi. $^{31}$

1902- The law on land ownership was made more specific. It connected ownership more firmly to language by assigning a Norwegian name to properties. These names later became family surnames. ${ }^{32}$

The intent of the legislation was clear: solidarity of culture throughout Norway through the supplanting of Sámi cultural practices with Norwegian ideas, ideals, culture and language. By enacting legislation tying land rights to language competency, Norway manipulated adult Sámi into learning and adopting Norwegian language and customs in order to maintain a livelihood and rights to traditionally-managed land. Education policies ensured young Sámi were educated in Western ideals, and Norwegian language and customs. These legislative practices guaranteed a change in traditional values because Sámi parents desired success for the younger generation of Sámi, without the added stigma of being culturally different. In order to achieve the goal of Norwegianization, or Fornorsking, the Norwegian government used multiple tactics.

There were many trends in the Norwegianization policy. Through active colonialism: Sámi were clearly to be assimilated into Norwegian society and they were to obliterate the Sámi language...Through implied colonialism: it was

\footnotetext{
${ }^{27}$ Ibid.

${ }^{28}$ Ibid.

${ }^{29}$ Ibid.

${ }^{30}$ Lehtola, The Sámi People: Traditions in Transition, p. 44.

${ }^{31}$ Ibid.

${ }^{32}$ Ibid.
} 
possible the Sámi could become civilized by converting to Christianity and by reading general refined literature in Sámi. ${ }^{33}$

Government policy therefore maintained that, for the good of the inferior Sámi culture, the dominant and superior Norwegian culture would be learned and in the process bring the Sámi to enlightenment and endow Sámi with Western values. "By civilizing the Sámi it would be possible to direct them into the Norwegian language and culture." 34 The white man's burden placed the weight of enlightenment on the shoulders of Norway, and the pressure of that perceived weight validated actions taken to strengthen Norway against outsiders.

With these common ideas linking European imperialist practices and the goals and intentions of the Japanese, how and why have the results in Norway differed from the actions undertaken by Japan? In Norway, "The international re-examination of human rights after World War II, which had been fuelled by its abuses, made it impossible to carry on with the accustomed nationalistic attitudes." 35 The proximity to Europe and the aftermath of World War Two influenced the actions not only in Norway, but throughout Europe. This allowed for new rights and protection for minorities in their cultures, languages and traditions. The common histories and shared cultural experiences in Europe allowed for the persuasion of ideas after World War Two, especially in the aftermath of imperialism and nationalism that had been taken to extremes. "In the atmosphere of changing ideology, ideas about the value of individuals and the rights of small peoples and minorities improved so that the United Nations added an important section to its Charter securing serious attention for the priority of aboriginal peoples' rights." 36

The pressure that had once driven European countries to imperialist actions now confronted widely held beliefs and practices. "The new attitudes, along with scientific research, overturned the racially prejudiced images of Sámi that had been widely presented and publicized before the war." ${ }^{37}$ Not only the community within Norway, but also communities within Europe placed emphasis on the rights of minorities in nations. "Samuli Aikio states that by entering into new agreements and resolutions, the Nordic countries began to reexamine their attitude toward their national minorities." 38 The Sámi then benefited from the influence the Nordic countries had placed on one another to make changes to policies aimed against the Sámi. While previous competition between the Nordic countries had created policies aimed at eradicating the Sámi culture, new pressures ensured that as one Nordic country passed legislation to benefit Sámi culture the others would then follow. These legislation changes and changes in attitude culminated in an act to benefit the Sámi, "Following Norway's ratification of the International Labor Office (ILO) convention on indigenous peoples in $1990,{ }^{39}$ the Norwegian parliament acted to strengthen official use of Sami, and to declare

\footnotetext{
${ }^{33}$ Ibid., p. 45.

34 Ibid.

${ }^{35}$ Lehtola, The Sámi People: Traditions in Transition, p. 58.

${ }^{36}$ Ibid.

${ }^{37}$ Ibid.

${ }^{38}$ Ibid.

393 Articles 27 and 28 concern rights to independent forms of education and general language rights: governments shall recognise the right of these peoples to establish their own educational institutions and facilities, provided that such institutions meet minimum standards established by the competent authority in consultation with these peoples ... Children belonging to the peoples concerned shall, wherever practicable, be taught to read and write in their own indigenous language or in the language most commonly used by the group to which they belong. (ILO 1990:16)
}

22 | Journal of Contemporary Eastern Asia, Volume 8, No.2 
Sami and Norwegian as equal languages with equal status." ${ }^{40}$ Why then was Japan's response not a mirror of Norway's actions to right past wrongs? The status of the Sami as a minority population within Scandinavia allowed Sami culture to become protected. The changing ideology in Europe disallowed the continuation of mistreatment and colonization of aboriginal minority groups within Scandinavia. In comparison to China, how does one protect the culture and reproduction of a culture of a population in the billions? The 'protection' that was now needed for the Sami culture could be looked at in a sense of parental obligation invoked by European imperialism; the unequal power relations still play a role in what a dominant culture allows and provides for a minority culture. The role imperialism played in the conflict between Japan and China led to a different outlook and result. "Some Japanese insisted that 'Japan's war was fought as a war for cultural progress' and praised the looting of books as a strategic weapon and as a unique phenomenon in world history." ${ }^{41}$ The outlook of Japan concerning the goals and intentions of creating the Greater East Asia Co-prosperity Sphere were not eradicated by a stronger Asian force. The West's power in stopping Japan's territorial expansion did not change the outlook of Japan as the culturally superior Asian power. Even with defeat, the resurgence of the Japanese economy and the rebound of Japanese culture have further solidified Japan's outlook. In aftermath of the Second World War, Japan became the center for learning in Asian studies. "These books provided Japanese scholars with the most treasured materials for the study of China and enabled Japan to become the foremost center for Chinese studies." ${ }^{42}$ By keeping the cultural property Japan looted, the Japanese were then able to preserve their role as the superpower among the Asian countries and continue to retain a hold over the education and history of China while at the same time keeping China at a disadvantage because Japan holds the nation of China's greatest treasure - China's past. "The Japanese libraries housing these books from China and other nations have now become the best libraries in the world for the study of Asian culture and history, where people can find books that cannot be found anywhere else." 43 The status of Japan is therefore maintained as the cultural superior in Asia, and the responsibility of overlooking and maintaining knowledge of Asian studies became the new imperialist burden of Japan.

The Tokyo Imperial University, "which houses the priceless collection of the oldest and largest collection of Chinese classical texts, and the world's oldest and most extensive collection of printed texts. Only a small portion of this material is not accessible to historians inside or outside of Japan. ${ }^{44}$

By controlling access to cultural resources, Japan maintains control over the knowledge and history of Asia and strengthens Japan's position as agent. With China's association and with communism and closed door policy, Japan's open access policy towards learning about Asian culture fortifies Japan's better-qualified position as manager and authority on Asian culture. Although Japan does not employ imperial expansionist tendencies currently, the control over the knowledge and cultural history of Asia empowers and embodies the continuation of an imperialist mindset in Japan. The paternal penchant noted in imperialistic actions can be seen

\footnotetext{
${ }^{40}$ David Corson, "Norway's "Sámi Language Act": Emancipatory Implications for the World's Aboriginal Peoples," Language in Society, Vol. 24, No. 4 (Dec., 1995), p. 500.

${ }^{41}$ Jianmin, "The Looting of Books in Nanjing," p. 281.

42 Jianmin, "The Looting of Books in Nanjing," p. 286.

${ }^{43}$ Ibid.

${ }^{44}$ Adachi, Masataka, "Daichi, niji seai taisenchu ni okeru nihongun sesshu tosho [Books taken by the Japanese Army during the First and second World War]," The Library World, 32.2 (July 1981), p. 69., quoted in Zhao Jianmin, "The Looting of Books in Nanjing," in Peter Li, eds., The Search for Justice: Japanese War Crimes (New Brunswick: Transaction Publishers, 2003), p. 286.
} 
in the repatriation of books from Japan to China. "Although some 158,873 volumes have been returned to China in the intervening years, it constitutes 6 percent of the total number taken, i.e., 2,742,108 volumes. The major portion has not been returned." 45 The idea that China is not ready to have control over such cultural assets is evident in the continued possession of China's cultural property. China's history and association with communism further exacerbates China's claims on her, China's, cultural property. Japan's role as protector and facilitator of knowledge not only maintains a parental role of an imperialist nature, Japan furthermore holds China's history hostage to the disadvantage of China. Currently, "Even scholars from China must go to Japan to consult these precious volumes." 46

The influence of European imperialism can be seen in the past actions of Japan and through the continued grip Japan maintains on China's cultural property. Although Western thought and ideals have developed and changed over time concerning the rights of peoples to cultural property, the lack of Asian pressure coupled with the consent of the West have allowed Japan to have continued control over China. Through the veil of imperialism, Japan was able to impose control over China during the early nineteenth century. Through the West's lack of initiative concerning these cultural rights as well as China's inability to assert itself, China's, inability to retrieve lost cultural property and the issue of control of cultural property has culminated in the continuation of Japan's imperialism over China. Because the idea of what constitutes cultural rights and property remains ambivalent, Japan's imperialist possession and control of Chinese cultural artifacts continues, and the crime of the cultural looting of China remains unresolved. Scott Leckie proposes that, "Problems of perception and resolve, rather than any inevitable limitation of law or jurisprudence, have kept economic, social and cultural rights wallowing in the relative purgatory of global efforts to secure human rights." 47

\footnotetext{
${ }^{45}$ Zhao Jianmin, "The Looting of Books in Nanjing," p. 285.

${ }^{46}$ Ibid., p. 286.

${ }^{47}$ Scott Leckie, "Another Step Towards Indivisibility: Identifying the Key Features of Violations of Economic, Social and Cultural Rights" Human Rights Quarterly, Vol. 20, No. 1. (Feb., 1998), p. 82.
}

24 | Journal of Contemporary Eastern Asia, Volume 8, No.2 


\section{Bibliography}

Ashcroft, Bill, Gareth Williams, and Helen Tiffin, Post-Colonial Studies: The Key Concepts (New York: Routledge, 2000).

Chiang , May-ling Soong, "Response letter to U.S. doctor" (Headquarters of the Generalissimo, Wuchang, China, February 25, 1938) in War Messages and Other Selections. Hankow: The China Information Committee, 1938.

Chiang, May-ling Soong, "Young China's contributions to world thought being disrupted by Japanese destroyers of culture" (Madame Chinang Cables to U.S. Students) in War Messages and Other Selections. Hankow: The China Information Committee, 1938.

Corson, David, "Norway's "Sámi Language Act": Emancipatory Implications for the World's Aboriginal Peoples," Language in Society, Vol. 24, No. 4 (Dec., 1995), pp. 493-514.

Jianmin , Zhao, "The Looting of Books in Nanjing," in Peter Li, eds., The Search for Justice: Japanese War Crimes. New Brunswick: Transaction Publishers, 2003.

Leckie, Scott, "Another Step Towards Indivisibility: Identifying the Key Features of Violations of Economic, Social and Cultural Rights" Human Rights Quarterly, Vol. 20, No. 1. (Feb., 1998), p. 81-124.

Lehtola, Veli-Pekka, The Sámi People: Traditions in Transition. Fairbanks: University of Alaska Press, 2004.

Merryman, John Henry, "Two Ways of Thinking About Cultural Property," The American Journal of International Law, Vol. 80, No. 4 (Oct., 1986), p. 831-853.

Suma, Yakichiro, "A Long View of the East" (Address at the "Japan Night" Program, International Student's House, Philadelphia, Pa., March 3, 1939) in Where Japan Stands;Addresses Delivered in America on the Sino-Japanese Conflict. Tokyo: The Hokuseido, 1940.

Suma, Yakichiro, "New Order in East Asia" (Published in the "Harvard Guardian," April, 1939) in Where Japan Stands; Addresses Delivered in America on the Sino-Japanese Conflict. Tokyo: The Hokuseido, 1940.

Suma, Yakichiro, "What Japan Wants In China" (Address before the Buchnell University Christian Association, Lewisburg, Pennsylvania, December 10, 1937) in Where Japan Stands; Addresses Delivered in America on the Sino-Japanese Conflict. Tokyo: TheHokuseido, 1940.

Suma, Yakichiro, "Where Japan Stands" (Address before the Economic Club of Detroit, Michigan, December 12, 1937) in Where Japan Stands; Addresses Delivered in Americaon the Sino-Japanese Conflict. Tokyo: The Hokuseido, 1940.

Union of Democratic Control, Eastern menace; the story of Japanese imperialism. London: Union of Democratic Control, 1936. 